\title{
Resolving the start-up identity crisis: Strategizing in a network context
}

\author{
Sari Laari-Salmela* \\ University of Oulu Business School, Department of Marketing, Management and \\ International Business, P.O. Box 4600, 90014 University of Oulu, Finland, Tel. +358 294 \\ 483 922, sari.salmela@oulu.fi \\ Tuija Mainela \\ University of Oulu Business School, Department of Marketing, Management and \\ International Business, P.O. Box 4600, 90014 University of Oulu, Finland, \\ tuija.mainela@oulu.fi \\ Vesa Puhakka \\ University of Oulu Business School, Department of Marketing, Management and \\ International Business, P.O. Box 4600, 90014 University of Oulu, Finland, \\ vesa.puhakka@oulu.fi \\ *) corresponding author
}

\begin{abstract}
The objective of the present study is to examine the strategizing of start-ups in a network context. The paper depicts start-up strategizing as an intertwined activity of identification and boundary-drawing. The questions of network identity and network boundaries become salient in times of disengagement by a primary customer or when there is a need for significant redirection of the business during what is referred to as a network identity crisis. The study emphasizes the viewpoint of an entrepreneur as strategist and builds on the concept of network identity to stress the socially structured individual cognition of who the organization is in light of its network connections. We study strategizing in four start-ups with different identity crises. By applying a grounded theory approach and Gioia methodology, the paper models the dynamics of restart strategizing in terms of its internal and external triggers and the choices when managing three identity-related contradictions. Furthermore, we characterize four alternative restart strategies connected to the identities and boundaries perceived by the entrepreneurs. By embracing the way start-up's identity and its strategy evolve interdependently in relation to the network dynamics, the model contributes to our understanding of those strategizing activities whereby restart can occur.
\end{abstract}

Keywords: start-up, network identity, strategizing, boundary-drawing, identification 


\section{INTRODUCTION}

The network concept plays a key role in a number of seminal articles that deal with startup creation and development (Birley, 1985; Aldrich \& Zimmer, 1986; Uzzi, 1997; Keeble \& Wilkinson, 1999). Later research also constantly notes the significance of networks for small firms (see Araujo \& Easton, 1996; Hoang \& Antoncic, 2003). Networks have been suggested to be more important than an individual's characteristics for the development of start-ups. Still, deeper analyses of the network activities of start-ups are scarce (La Rocca, Ford \& Snehota, 2013). There are only a small number of studies that have contributed to our knowledge of the actual existence of start-ups in networks and their strategic activity within networks (Aaboen, Laage-Hellman, Lind, Öberg, \& Shih, 2016). In the present study, we focus on the strategizing of start-ups within networks and use network identity as a lens to study the crises that start-ups face after their establishment.

By strategizing we mean an ongoing effort that follows the routinized ways of both proactively making moves to find future direction for the development of the firm as well as reacting to changes in the network. Strategizing of a firm is intimately related to its identity in networks (Johanson \& Mattsson, 1992; Anderson, Håkansson \& Johanson, 1994; Huemer, 2004). Identity is here understood as a sense of "who we are" as an organization (Albert \& Whetten, 1985) embedded in organization's practices and manifested in, but also changed by, organizational activities ("what we do") (Gioia, Schultz, \& Corley, 2000). Identity in network context captures a company through its connections with other companies with respect to how a company is perceived by others, and how a company perceives itself, and its position, based on its network connections (Anderson et al., 1994). Identity, therefore, amalgamates strategic choices made early on with the network identity a firm obtains by its relationships to other actors (Huemer, 2013). We use the concept of network identity to refer to the way the identity is defined both "inside-out" due to the internal volitions and cognitions of the individuals and 
"outside-in" affected by the relationships the organization has (Håkansson \& Ford, 2002; Huemer et al., 2013).

We should find it valuable to look at start-ups not only as the beneficiaries of the network resources or resource coordinators in the networks, but as manifestations of the inherent contradictions of strategizing within networks. With contradiction we refer to the "simultaneous presence of two essential elements that are connected or interrelated yet directly opposed” (Farjoun, 2017: 89). Network paradoxes (Håkansson \& Ford, 2002) represent a particular type of contradiction: how the network dynamics are based on unity of opposites: influencing versus being influenced, controlling versus being out of control, and opportunities versus limitations. Strategizing activities can trigger identity change (Gioia et al., 2000) when the firm reconsiders the choices made. The event of reconsideration often means an identity crisis for a small firm which in the startup might have relied on close relationships with its key customers and other partners. This is characteristic of many software and high-tech start-ups whose relationships with their first customers can be strong or even symbiotic, particularly when the start-ups are spin-offs (Ruokolainen \& Igel, 2004; Aaboen, Dubois, \& Lind, 2011; Bosch, Olsson, Björk, \& Ljungblad, 2013). Therefore the identity crises in start-ups are crises of network identity. The research question addressed in this study is: How do start-ups strategize in an identity crisis within a network context?

The paper builds on research both within and outside the industrial marketing and purchasing tradition. In characterizing start-ups, we rely on the literature on software start-ups (e.g., Bosch et al., 2013; Paternoster, Giardino, Unterkalmsteiner, Gorschek, \& Abrahamsson, 2014) and start-ups in networks (e.g., Baraldi \& Strömsten, 2009; Aaboen et al., 2016; Baraldi \& Havenvid, 2016). On the basis of the argumentation by Huemer and his colleagues (Huemer, Becerra, \& Lunnan, 2004; Huemer, 2013), we then depict start-up strategizing in networks as an activity of identification and boundary-drawing. Relying on the ontology of becoming in 
the management field (see Jing \& Van de Ven, 2016), we see both identity and strategy as paradoxical and requiring acceptance of their inherent dynamism and related contradictions. This resonates well with our understanding of the nature of acting in boundaryless business networks (see Håkansson \& Ford, 2002). Hence, what makes this study significant is that, in contrast to the investigations of the way of identity and strategy being in organizations, we focus on their becoming when strategizing within a network context.

We suggest that the questions of network identity and network boundaries become particularly salient in times of profound change in the relationships of the start-ups. We therefore chose to study software start-ups' identity crises caused by the disengagement by a primary customer or the need for a significant redirection of the business from the initial business networks. By applying the grounded theory approach, we model the dynamics of restart strategizing in terms of its internal and external triggers and the choices with respect to managing three contradictions of network strategy. With network strategy we refer to the logic underlying the firm's activities that is constantly being produced and reproduced through the strategizing activities and therefore characterize four alternative modes of strategizing as restart strategies.

In what follows, we start with an overview of research on start-ups in networks and startup identity. We then advance a framework of start-up strategizing within a network context. The third section describes the empirical research setting and the methodology, and the fourth section deals with the analysis of the empirical data. In conclusion, we discuss the contributions of the study in terms of identity-related contradictions of strategizing by start-ups.

\section{STRATEGIZING OF START-UPS WITHIN A NETWORK CONTEXT}

In the present section, we first discuss the paradoxical nature of start-up strategizing in networks, and then move on to present the identity lens to strategizing. We specify start-up 
identity (i.e., self-perception of the organization) and strategizing (i.e., activity through which the start-up produces itself) as inseparably related to each other. Identity is the starting point for strategizing; and through strategizing, identity changes.

\subsection{Start-up strategizing in networks}

A start-up is generally defined as a legally independent company that is no older than ten years (Burgel \& Murray, 2000). Start-ups rarely own all the resources they need, and the search and acquisition of resources is what early on embeds the firms to business networks (Araujo \& Easton, 1996; Hoang \& Antoncic, 2003). Thus, one of the main start-up activities is to ensure that the other actors in the networks acknowledge the start-up as being worth the investment of their resources. Obtaining resources from networks for a start-up is seen to be related to the entrepreneur's skill in legitimizing the firm and their networking capabilities (McGrath \& O'Toole, 2013; Naudé, Zaefarian, Tavani, Neghabi, \& Zaefarian, 2014). Furthermore, start-ups need to reconcile and adapt various resources and to construct mutual interests among a variety of actors (Baraldi \& Strömsten, 2009; Baraldi, Gregori, \& Perna, 2011; Strömsten \& Waluszewski, 2012; Baraldi \& Havenvid, 2016). These are the initial strategic choices which make a legally independent start-up exist through the relationships it creates and through which it becomes dependent on a network.

Start-up strategizing in a network context is, therefore, a question of resources and interdependencies. It is about making choices concerning relationships and networking to combine and recombine resources - strategic change implying major changes in relationships (Mattsson, 1988; Gadde, Huemer, \& Håkansson, 2003). Much of the strategic interaction in the initial relationships are then about learning: learning about the resource interfaces (Aaboen et al., 2011) and 'worlds' of customers (Öberg, 2010). Yet, strategizing is paradoxical in nature: strategic choices affect relationships, but the relationships influence the firm's strategic choices 
(Håkansson \& Ford, 2002; Schepis, Purchase, \& Ellis, 2014). It is about influencing and being influenced, which is manifested as a mix of management activities the objectives of which are to effect changes, and which themselves are reactions to the changes in the relationships (Håkansson \& Snehota, 1995; Mintzberg, Ahlstrand, \& Lampel, 1998).

In the start-up phase, the relationships a firm builds define the firm to the core - not only strategy-wise but also identity-wise (Prashantham \& Birkinshaw, 2008). To support its perception of who the start-up is, the company seeks to manage its relationships to support its views (cf. Håkansson \& Ford, 2002). But as identity is formed on the basis of positions in a network and in relation to the identities of others (Johanson \& Mattsson, 1988), an actor has only certain control over its identity. An organization's identity develops in the interaction between the characteristics of the focal actor and the characteristics of other actors (Huemer, 2013; Schepis et al., 2014). This highlights the paradoxical nature of identity as it depends, as does strategizing, on the inside dialogue of the firm and the inside dialogue of other organizations and their impact. Neither strategy nor identity can be fully controlled by a firm and its managers. Still, identity is a strong determinant of strategy and involves the effort of controlling one's own position in the network. Control is also to be balanced because for subcontracting start-ups, more control can mean losing the possibility to strengthen their position through independent research and development.

Several studies suggest that start-ups are particularly dependent on their first, major customer relationships (Aaboen et al., 2011; La Rocca et al., 2013). This is particularly true for small software start-ups that provide professional services or enterprise solutions: their business is based on people, both on the clients/partners and the employees, rather than the strategy and marketing focus by product firms (Hoch, Roeding, Purkert, \& Lindner, 1999; Paternoster et al., 2014). Subcontractors and professional service provider type of start-ups are the most dependent on their main clients, especially when they are based on different forms of 
outsourcing or "quasi-outsourcing" (Väyrynen \& Kinnula, 2012; Bosch et al., 2013). Still, initial relationship development with a wide variety of parties and the conscious building of business networks are noted crucial in accessing and producing knowledge for technological innovation and commercialization of innovations by start-ups (Palo \& Tähtinen, 2013; Aarikka-Stenroos, Sandberg, \& Lehtimäki, 2014; Baraldi, Ingemansson, \& Launberg, 2014; La Rocca \& Snehota, 2014). The questions of the number and type of needed relationships in start-ups is directly related to the issue of network boundaries. They are entwined in the paradox of opportunities and limitations, according to which the stronger the ties, the more vital they are; but they will also restrict freedom of change.

\subsection{Strategizing intertwining with network identity}

Organization researchers have for a long time connected the strategy of a firm to the organizational identity reflected in its decision-making (Dutton \& Dukerich, 1991; Reger, et al. 1994; Ashforth \& Mael, 1996). According to Ashforth and Mael (1996: 33), "self-definition and strategic choice are intertwined such that an organization may enact and express a valued identity through strategy and may infer, modify, or affirm an identity from strategy and the responses it evokes". Identity as an answer to the question 'who we are' (Albert \& Whetten, 1985) relates to how experiences are interpreted and understood, and in that way, how strategies are developed, chosen and evaluated (Huemer, 2004). Identity research has been carried out on both the individual level (Alvesson, 2001; Lindgren \& Wahlin, 2001) and the organizational level (Albert \& Whetten, 1985; Rindova \& Fombrun, 1998; Pratt \& Foreman, 2000). More recently, a situated view of identity has been called for (Albert, Ashforth, \& Dutton, 2006).

A situated view is provided by industrial marketing and purchasing researchers' studies on identity at the network level (Anderson et al., 1994; Huemer et al., 2004; Öberg, Grundström, \& Jönsson, 2011; Ellis, Rod, Beal, \& Lindsay, 2012; Huemer, 2013; O'Malley et 
al., 2014; Schepis et al., 2014; Purchase, Da Silva Rosa, \& Schepis, 2016). Identity is seen to play a major role in differentiating between various relationships and providing guidance on how to behave within them (Huemer, 2004; Huemer et al., 2004; Bonner, Kim, \& Cavusgil, 2005; Öberg et al., 2011). Earlier organizational identity was considered something relatively stable over time (e.g., Albert \& Whetten, 1985), but due to the dynamic nature of business networks, network identity of a start-up changes as new relationships are built and old relationships are dissolved (Anderson et al., 1994). Therefore, the identity cannot be seen as static but rather in a constant state of becoming (Jing \& Van de Ven, 2016).

\subsubsection{Identification and boundary-drawing as strategic activities}

The concept of network identity has been used to refer to the distinct identity that a firm obtains by its relationships with other actors (Johanson \& Mattsson, 1992; Anderson et al., 1994; Håkansson \& Snehota, 1995; Huemer, 2004; Purchase et al., 2016). Network identity has also been used to highlight the image a firm has to others, referring to the way actors are positioned in a network and perceived as valuable counterparts, or the attractiveness of a firm as an exchange partner (Anderson et al., 1994; Gadde \& Håkansson, 2001; Hatch \& Schultz, 2002). In comparison, Huemer (2013) presented the notion of 'organizational identities in networks'. Here we build on this perspective and use network identity as a relational concept to draw attention to the mutual constitution of firms and networks and the related identities.

In this study, a network identity is approached from the perspective of 'how identity becomes' rather than from the perspective of 'what is the identity' (Gioia et al., 2000). This viewpoint counters the identity perspectives that are interested in finding the order from the characteristics and activities of organizations, and thus the variables explaining the identity (see, e.g., Albert \& Whetten, 1985). The emphasis is on identification as a sense of oneness with or belongingness to an organization (Mael \& Ashforth, 1992) and as a connection with 
actors in its surrounding network (O’Malley, O’Dwyer, McNally, \& Murphy, 2014). It is a social activity where the actor is its own appearance builder and transformer (Cerulo, 1997) but the identity is still more a reflection of its context than the actor's accomplishment of its core essence (Anderson et al., 1994). Identification is a continuous process whereby "actors simultaneously imagine, visualize, and experience identities depending on the boundaries that are drawn, the meanings that are understood, and the set of relationships that are acted upon" (Huemer et al., 2004: 64). It therefore defines the perceived limits of strategic action.

The identity of a firm is defined by its organizational boundary, which dictates who are (and who are not) members of the organization (Huemer, 2013). Boundary is a conceptual distinction made by social actors to categorize objects, people, practices, or even time and space (Lamont \& Molnár, 2002: 168). Boundaries separate people into groups and generate feelings of similarity and group membership (Epstein 1992: 232). The idea of the boundary has been closely associated with the idea of 'organization' (Hernes \& Paulsen, 2003). However, boundaries have also a wider meaning in organizations as actors use symbolic resources to create, perpetuate, or challenge institutionalized differences or inequalities by creating distinctions between, e.g. "us" and "them," the "in" or "out" (Heracleous, 2004). In other words, boundaries create distinctions between entities in a network context: who we are as an entity in comparison with the other entities in the network, or the network as a whole. Moreover, boundaries exist at different levels (mental, social, and physical), and organizations operate within multiple sets of co-existing boundaries that relate either to core ideas and concepts that are particular to the firm (mental boundaries), to social bonding that ties the group or organization together (social boundaries), or to formal rules and physical structures regulating human action and interaction in the group or organization (physical boundaries) (Lefebvre, 1991; Scott, 1995; Hernes, 2004).

As actors may view the network, its boundaries and the nature of its exchange 
relationships in different ways - none of which need coincide with the possible description provided by an analyst who is not an actor (e.g., Johanson \& Mattsson, 1992; Huemer et al., 2004) - the nature of the network is indeterminate. The way actors draw boundaries denotes strategic choices, which on one hand are always dependent on the identity. On the other hand, boundaries denote a starting point for identification. The way a firm imagines and understands the boundaries of itself and others "affects firm's identification of other actors as well as its possible identification with them" (Huemer et al., 2004). Boundary-drawing is the activity of using boundaries as tools by which individuals and groups struggle over and come to agree upon definitions of reality (Lamont \& Molnár, 2002: 168).

\subsubsection{Dynamics of start-up strategizing}

Previous research stresses that the dominant activities of the network maintain the established identifications (roles) (Purchase et al., 2016). Institutionalized ways of working within a network require organizations to identify in a certain way. Often organizations also produce and even demand from other actors an identity that is expected from them. Organizations' commitments are made "irreversible" by the degree to which they are made central to policies, procedures, and practices (Selznick, 1957) - within and between organizations. Even though relationships end and networks change, the governing logic of an organization's activities may remain, affecting also the way firms strategize for their future direction. We argue that this is also the reason for the difficulties that software start-ups (established on a heavy dependence on their clients) face with their strategizing when they need to start over after changes in these major relationships.

However, organizations also challenge institutionalized forms of identification and explore the boundaries of identification (Fiol, 2002; Greenwood \& Suddaby, 2006; Ravasi \& Schultz, 2006; O'Malley et al., 2014). Change processes in organizations are about creating, 
moving, or consolidating boundaries (Hernes, 2004), and in these situations, new ideas will arise about what and who the organization could be. These boundary-spanning identification practices, apart from changing the dominant identifications, produce new forms of identity (Oliver, 1992). Hence, identity is fundamentally changing and multi-dimensional (Öberg et al., 2011; Purchase et al., 2016) and becomes apparent and transforms in interactive strategizing (Scott \& Lane, 2000; Schepis et al., 2014). This is why identification often comes across as an interactive narrative of how it might be possible to become someone (Somers, 1994; Ellis et al., 2012; Schepis et al., 2014).

Start-ups seek to narratively energize the social context by figuring out the value the startup could create for the network and by presenting a rationale for taking advantage of the resources of the network in this particular start-up (Ellis et al., 2012; Schepis et al., 2014). This means that the identification as an interactive process is a key instrument in creating a space within the network. The identification is then the activity that produces positions in the network from which it might be possible to create new value (O'Malley et al., 2014; Purchase et al., 2016). For this reason, the narratives on network identification are central to the development of understanding of start-ups within networks.

The way that organizations, and managers as individuals, identify themselves and the way boundaries are drawn are seen as interdependent, ongoing processes held together and changing by network identity (interpreted through the approach of organizational identities in networks), as illustrated in Figure 1. The core of strategizing in a network context lies in the way managers can (1) become aware of identity referents and the way boundaries are drawn both mentally, socially and physically; (2) create, move or consolidate these boundaries; and (3) manage the resulting instability in identity. Therefore, our conclusion is that if we want to understand how and why start-ups strategize in networks in the way they do, we must examine the activity that constitutes the identity formation of the start-up. In our view, the paradoxical 
situations between the dynamics of networks and start-ups' attempts at stabilization are at the core when trying to understand the start-up strategizing within networks. To understand the relationship between identity and strategizing, we focus on the network identity crises and examine the balancing by the startups between their inner world and the network reality through strategic activities of identification and boundary-drawing.

Insert Figure 1 about here.

In what follows, in order to study strategizing of start-ups in networks, we adopt identity as a lens with the aim of shedding light on our empirical findings based on grounded theory analysis. We analyze the difficulties faced by start-up managers in the early phases of the firms and in the current business situation, and through theoretical integration, link the concept of network identity to the dynamics of start-up strategizing.

\section{METHODOLOGY}

The purpose of this study was to examine the strategizing done in different crises that small software companies face when their business situation does not correspond anymore to the choices made in the start-up phase. In order to gain insights into the different restart strategizing activities of the firms, we adopted a qualitative case study approach with a grounded theory analysis and approach for building the theory. This approach was selected because of its appropriateness for studying complex phenomena and developing further insights into existing theoretical perspectives (Locke, 2001; Birks and Mills, 2011). As there is little existing theory on restart strategizing, a more inductive approach was considered useful as it enabled a broad exploration of antecedents and outcomes of restart strategies. In particular, our approach 
largely follows the guidelines of the "Gioia methodology" outlined by Gioia and Chittipeddi (1991) and Gioia, Corley, \& Hamilton (2013).

Building on the grounded theory approach (Glaser \& Strauss, 1967; Lincoln \& Guba, 1985; Strauss \& Corbin, 1988), the idea of which is to use qualitative data to inductively develop theoretical descriptions of the contexts of the phenomena under study, the Gioia methodology aims to provide a systematic approach to new concept development and grounded theory articulation as "an attempt to bring 'qualitative rigor' to the conduct and presentation of inductive research" (Gioia et al., 2013: 15). As the research process unfolded, we decided to use the concepts of network identity, identification, and boundary-drawing to categorize the results. We follow the process described by Strauss and Corbin (1988) with the understanding that theoretical ideas can be brought into the analysis already in the middle of the process (Urquhart \& Fernandez, 2006).

\subsection{Data collection}

The context of the study is software business and four small firms operating in software project business (customized software business), enterprise applications and/or software product business. When developing customized software, the business is based on close relationships between the company and the customer. Their software is tailored not only to meet the requirements of a single buyer but they also operate on business models based on selling their expertise (e.g., Hoch et al., 1999). What makes strategizing challenging in these kinds of small firms is that, being based on professional service business while simultaneously driving internal product development, they are typically pursuing different kinds of business models at the same time. The challenge of strategy concerns prioritization between business areas as they require different kinds of resources both in operations and in management.

This study is a part of a larger research project on IT business in which 19 ICT-oriented 
SMEs in two provinces took part. After following these firms over several years and analyzing the first round of interviews with the companies, four of them were selected for this particular study. Since we wanted to focus on restart situations, we selected those firms that were either already struggling with restart strategizing or about to face a restart situation in the form of a change in management. Through comparative cases it was also possible to examine strategizing dynamics in different contexts. The characteristics of the companies are described in Table 1.

Insert Table 1 about here.

The primary data for this study were collected from 25 manager/management team member interviews from four companies, as indicated in Table 2 below. In two companies (Gamma and Delta), there was only the founder that was involved in strategizing activities. In Alpha there were two key persons involved and in Beta, three key persons.

Insert Table 2 about here.

The interviews were done within a time-span of several years since the firms were followed throughout the project and also some years after that. All the firms were followed until a "resolution" in the form of a merger or other type of change in management was accomplished. With Delta, the merger had already taken place during the first round of interviews (in 2006). MA from Alpha was retired, and a new CEO took over in 2009. Beta went through one merger and change of the CEO in 2008 but continued quite independently until another merger in 2015 , ending the existence of Beta as an independent firm. Gamma merged with a larger telephone company, and MG retired in 2010.

Each interview session had a specific theme, starting with 'business start-up' covering 
topics related to the start-up phase of the firm and continuing with 'managing the business' related to strategic issues and development of the firm as a whole, 'renewal of business' covering innovation-related topics, and 'biography' about the personal lives of the managers. The second round of interviews was conducted among three firms and concentrated on the theme of 'strategy formation'. The fourth round of interviews was about update with a theme 'future directions'. The length of interviews varied between 90 and 120 minutes. In addition to the primary interviews, the data of the research project as a whole consist of informal interviews and discussions (with managers, employees, and partners of the companies), participative observations on different occasions (such as seminars, training sessions, informal visits, and coffee breaks) and other collaboration activities. Researchers were also involved in the board activities of the local collaboration network association the companies were members of. Also secondary data, such as memos of interviewees, web sites, and sales materials were utilized in order to gain a general understanding of the firms.

\subsection{Data analysis}

At the first stage, we conducted substantive coding of the interview transcripts. During the open coding stage, we did not rely on any background information from the extant literature. Following the methodology outlined by Gioia et al. (2013), we started to build our theory of restart strategizing by categorizing the data based on the management challenges the managers were talking about. These formed the first order concepts of our analysis, and we aimed to maintain the concepts that the informants were using.

Next, we created broader themes based on our interpretations of the difficulties expressed by the managers. The second-order themes that we gave to the $1^{\text {st }}$ order concepts were 1 ) moving boundaries, 2) asynchronization with the network, 3) perceived image dissonance, and 4) perceived identity dissonance. While creating the second-order themes, we also conducted 
a literature review while concentrating on research on network identity and strategizing. Next, we distilled the $2^{\text {nd }}$ order themes into three aggregate dimensions: 1) triggers of restart, 2) balancing contradictions, and 3) restart strategizing. With the help of the concepts (network identity, identification, boundary-drawing) integrated from the extant literature, we assembled the terms, themes, and dimensions into a data structure (Gioia et al., 2013) presented in Table 3.

Insert Table 3 about here.

Finally, we searched for relationships between the $2^{\text {nd }}$ order concepts in the data structure and found connections between boundary-drawing, identification, and identity in the context of restart strategies. We then transformed the static data structure into a dynamic grounded theory model and compared the model with the existing literature in order to better relate the concepts to the extant literature. The model discovers the underlying network strategy dynamics and the fluid nature of both strategy and identity of small firms. The results of the analysis are explained in the next section.

\section{RESTART STRATEGIZING IN A NETWORK CONTEXT}

In the analysis, we formed themes based on the difficulties faced by managers in the current business situation and earlier. Three dimensions emerged from the analysis: (1) triggers of restart, (2) balancing contradictions, and (3) modes of restart strategizing. Contradictions existing on the everyday level of activities arise from the underlying paradox of dependenceindependence (of which also the network paradoxes by Håkansson \& Ford (2002) stem from). Managers aim to deal with these contradictions by ongoing strategizing: boundary-drawing and identification. When this established way of considering their business does not work anymore, 
identity crisis ensues.

The crisis is launched by triggers through which the managers become aware of the significantly changed situation. Triggers arise out of the same dynamics of network strategizing when the dissonance between network reality and internal intentions increases. Triggers relate either to changes at the network level or to the way the managers perceived their firms in relation to others. The struggle that ensues relates to developing new modes of strategizing, and hence, restart strategies. Here, we understand strategies as something that are "in the making" or becoming; not as something that "is", as a plan, for instance, but as a mode of strategizing. The model of the dynamics of restart strategizing is presented in Figure 2 below.

Insert Figure 2 about here.

\subsection{Identity crisis of the firms and a need for a restart}

As a start-up, Alpha was a spin-off from an ADP (automatic data processing) department of a local dairy. It primarily served dairies, on the basis of the competence and knowledge of the customers created through particular first-hand experience within the dairy industry. However, the business from centralizing the dairy industry soon started to decline. The identity of a specialized supplier in the dairy industry needed to be changed to a more generalist IT company in wider technology networks. However, the change proved difficult, as they did not find a partner with whom to anchor in a new network. This meant a crisis manifested as a lost network identity: their strategizing practices acquired in the beginning did not enable the firm to react to shifting boundaries or to shift and draw boundaries themselves. With an operational orientation, strong identification with the organization, and without clear network boundaries, their strategies were dependent on their partners. Hence, their choices for crisis resolution could be summed up as a search for a new strategic partner to function as an anchor to a new industrial 
network. We call this method of restart strategizing "anchoring”.

Beta was a joint start-up between MB and a large client company, a general software system provider that provided $100 \%$ subcontracting for this client. Even though the plan was to grow and sell Beta back to the client in a few years, the client suddenly left Beta a couple of years later. This was a brief moment of an identity crisis. However, identification with other parts of the business network (local networks and regional collaboration) combined with their strong sense of identity from other sides (local networks and group memberships; competences, distinguishing organizational practices) helped them recover from the loss and actively find new ways to draw boundaries, i.e., to define what they do and what they do not do, and who they are and who they are not.

Since then, Beta has been anchoring into different networks through different partners and thus using a similar restart strategy as Alpha but more proactively and with the goal of moving from the outer layers of the network closer to the core and attempting "a jump" from local to global networks. Through this kind of strategizing, Beta found a new niche within mobile vehicle information systems and an OEM within that local strategic network. A few years later, Beta merged with a large telephone company trying to restart on its own as a software house. The manager was replaced, and even though Beta continued its normal business, the new manager and the new sibling organization under the same parent brought in new data center service business. Finally Beta was merged into this sibling firm, becoming a data center service provider.

While searching for stability through partners and resources for its own product development, Beta's network identity changed from time to time; and learning to strategize in times of shifting boundaries and network identity dissonance was the greatest lesson from the start-up identity crisis. After the first crisis, this kind of "network leveraging" with an innovation orientation, network identification and indeterminate network became a consistent 
strategy: a systematic way of developing themselves through the network and re-inventing their business over and over again.

Like Alpha, Gamma was also a spin-off. It was based on the management system developed earlier for the forest department of a paper company where MG was working. As a start-up, the firm was tightly identified as a management system provider for the paper companies. During the course of wide mergers in the whole industry, Gamma lost nearly all of its customers. Despite the setback, Gamma adapted to the shifting boundaries and continued its business as usual with the remaining customers. There were no sources of growth or network-internal development in sight, and the operation principles and the business of Gamma corresponded to the original idea - to keep the company profitable. This basis had not prepared Gamma for strategizing in a crisis situation, but they relied solely on basic operations. Their identity remained rock-solid, even though some identity dissonance was experienced due to the decline of existing markets that MG had recognized, and he was aware of the map applications that would offer new business opportunities. But since he was about to retire, the active strategizing phase of the firm had to wait until he had sold the company to a larger local telephone company. The changes required were radical (from operations to innovation; organization-focus to network-focus; and shifting the network boundaries from the defined network to find and create opportunities beyond the existing business area), but actions were yet to be taken. Therefore their strategic activity for crisis resolution could be summed up as "postponed actions for re-inventing the business".

Delta was a software service provider start-up based on subcontracting for a large client firm. It was built around its founding manager (MD) and his way of building business. As he believed in passion, continuous learning and aiming high, these values were also embedded in Delta's distinctive practices. The company grew steadily and it had also other customers and internal product development. Delta had always avoided being customer-led and had been 
putting effort into internal development and innovation. To gain more resources for growth, Delta merged with Epsilon, a larger company. The operating principles and long-term goals did not correspond to the ideas that MD had originally had, and he felt like they were not able to perform in a way their customers were expecting them to perform. Both merged organizations were facing a crisis, manifested as a clash of cultures.

Delta had not experienced any dissonance in network identity before the merger with Epsilon, as the relationship with the subcontracting client had always been the guideline. In that sense, that part of the network had always been a strategic network, with a clear hub and identification to that network through that hub. However, due to the distinctive practices and related assumptions and beliefs, Delta had a clear sense of identity of its own. This helped him to also develop business outside of the strategic network. He believed in proactive development instead of just following the client, and he believed that this kind of acting was more valuable to the client as well. The identity crisis resulted from merging to a larger firm for which the client was just one, albeit an important customer, among others. The new merged company needed a restart as a whole - the former Delta as part of Epsilon, and Epsilon as part of Delta's network. In order to change the view of the organization to understand the importance of longterm customer relationship development and innovation, the mode of strategizing that MD was driving inside the new organization was that of "network identification", highlighting longterm innovation orientation, identification with the network, and recognition of the strategic network.

The firms ended up following different types of restart strategies because of their differing abilities to change commitments rooted in their practices during the start-up phase and ability to learn how to survive them. The modes of strategizing are defined here by the way the firms are dealing with the contradictions of innovation, identification, and network boundaries. First, to shed light on the way start-ups strategize in a network context and on the 
lessons start-ups need to learn in terms of strategizing, we need to understand the dynamics of network strategizing: how and why firms identify themselves and draw boundaries in terms of their business in a network context. Then, in the end of this section, we summarize the restart strategies as a result of these dynamics.

\subsection{Dynamics of re-start strategizing}

Strategizing is an ongoing effort that follows the routinized ways of both proactively making moves to find future direction as well as reacting to changes in the network. At the level of everyday activities, when solving problems and making decisions, the managers either reproduce or change their views on what they do (strategy) and who they are in the network (network identity). What drives this activity is the tension between their internal intentions (independence) and what is expected from them by others (dependence). The tension manifests itself in the everyday activities through three contradictions that managers need to balance. Restart triggers affect this balance but they also arise as a result of changes in the balance between a firm's contradictory needs, which results in notice that a restart is needed.

\subsubsection{Contradictions underlying network strategies}

The way the managers deal with these contradictions on an everyday level becomes rooted in strategizing practices which may prove difficult to change. Typically, the solution is usually not an either-or one; there is always a need for both, and therefore managers are forced to find a balance.

Identification with the organization and the network. Whether the firms identify themselves more as inside-out (in terms of what they do) or as outside-in (in terms of who they partner with) depends on the way the start-ups were established. Alpha and Gamma were more operationally focused ("it's no use to think about [strategic questions] since changes cannot be 
predicted"), and all development initiatives came from the customers ("customers say what to do"). They were IT professionals in another industry, whereas Beta and Delta were bundling their competence with OEM manufacturers and other subcontractors. Hence, the identification with the network was profoundly different. In a crisis situation, the way the balance had been drawn was either changed or needed to be reconsidered. After merging with another company, MD could no longer identify with the newly formed organization but remained committed to the network of customers and partners.

"At Epsilon, the first thing they said was that 'it's funny to hear you speak when you say that we do'... I meant the network." (Delta)

Even though a client would abandon a firm (like in the case of Beta), due to the availability of a wider network, new opportunities can be built with the help of existing relationships. They were constantly trying to balance the requirements of the internal strategy and the strategy driven by the partners. Although the same thing happened with Gamma (and also a bit more slowly with Alpha), as the customer base diminished significantly, new business opportunities were not that easy to create. Their identification was more with the firm as (operationally defined) a system service provider for a certain sector rather than a wider professional network, and drawing boundaries any other way proved difficult.

Innovating and stabilizing income streams. The existing relationships a firm has bring security and continuity, but at the same time they may prevent the firm from developing and providing the basis for future success. If preference is given to one over the other for a longer period of time, problems will occur, as in the case of Gamma, which was solving the contradiction of innovating versus stabilizing the income streams (relating to the general paradox of exploration and exploitation) by constantly prioritizing profitability ("I focused on keeping the company free from debt"). Changes were made when the customers regarded them as a necessity, but otherwise innovation was not something the company was aiming for. For 
Delta, the identity crisis related also to the changes in the balance. Before the merger, innovation had been an important defining factor for the company ("we have been active, doing our own thing and not just what the customer wants us to do"). It was believed that it was also the only way of maintaining the relationships in the long run. After the merger, the balance shifted towards prioritizing short-term profits ("now the situation tends to be that all the money should be just cashed out").

It is also typical for small firms in the software business that they get their basic income from customer projects, which also provide opportunities for learning. But the problem is that they tend to consume all the resources, and therefore it is difficult to make serious efforts in internal product development ("we first resource the subcontracting and projects, and the product remains in the background"). The problem also relates to the types of resources; unlike internal product development, customers require heterogeneous skills. Hence, in small firms providing software solutions (like Beta), balancing between these opposite directions takes place every day.

Defined and indeterminate network. Also, how the way the network is perceived and the boundaries are drawn - whether the network is seen as a closed one or an indeterminate one - is a question of balance. Boundaries are needed for the firms to be able to operate. If the network is seen as too indeterminate so that no boundaries can be drawn, like in the case of Alpha, defining oneself business-wise becomes difficult. On the other hand, the network needs to be seen as indeterminate in order to create opportunities by shifting the mental boundaries like in the case of Beta. They set out to find several larger customer partners (instead of just one) in order to balance business fluctuations. In this way, they become identified with the partners, but the network remains indeterminate in terms of business opportunities matching Beta's competence portfolio. However, when the boundaries are drawn according to the industry, like in the case of Gamma, the network is seen as closed with only a certain number 
of customers.

"If there were customer demand, then [development] would be natural. But we cannot create demand for these new customers, they are so large and live their own lives. We just aim to serve them." (Gamma)

This brings stability and security for the operations, making the objective of profitmaximizing possible; but at the same time, change and development independent of the customers become difficult. To move the mental boundaries drawn for a closed network actually requires seeing the network indeterminate first, like in the case of Alpha, who was looking for partners with whom to redraw and re-establish the boundaries.

\subsubsection{Triggers of restart}

The established ways of strategizing became questionable when the firms faced their identity crises. What brought up the perceived identity dissonance was a combination of external factors stemming from events faced by the organization (and also to some extent external to the manager) and internal factors related to the cognitive processes of the managers.

Moving boundaries. Moving boundaries are a natural part of network dynamics, but when the move makes it difficult or impossible for the firm to identify with the network, it can also denote a trigger for a restart. When an event is external to a firm, like when a client ends a relationship (Beta) or a whole industry reorganizes (Alpha, Gamma), the firm can actively notice the changes and be triggered to redraw the boundaries for themselves (Beta) or actively adapt to the boundaries set by the changes (Gamma). But even when it is the firm itself that is moving the boundaries, either mentally (Beta: re-visioning the network and finding new opportunities) or physically (Beta, Delta: merging with a larger partner with a wider clientele), it still has to cope with the changed vision of the network as the firms are also merging with each other's networks. For instance, Delta was used to a more far-reaching strategy, but the 
new merged organization had a much narrower vision of the network, focusing on selling resources at a standardized price:

"[The vision was] that we would be in this niche, in which we are operating, internationally known and a leading expert organization. But now it is going to change since in this firm they do not believe in such things, that it would be possible." (Delta)

Asynchronization with the network. Another trigger was when the firm was not able to keep up the pace required to satisfy its customers and partners. The managers felt that they were either lagging behind in development, not being able to innovate and create new things ("we don't actively create our own future"), or maintaining an outdated vision of the firm ("we have been executing the past"). Some of them also saw the firms as being slow in reacting to changes in the network ("when the move is finally made, others are there already"). These feelings were either due to external pressures from customers and partners (reflected in the perceived network image dissonance) and to internal strategizing struggles (resulting in too little time spent on product development) or to activities pursuing strategic goals instead of customer projects.

"We don't actively create our future, we take what we get; even the customer representatives ask what kind of role we would like to take in this business for real." (Delta)

We have been executing the past; we should think about the customer needs. (Gamma)

Perceived network image dissonance. The way firms become positioned in the network and act in relationships affects their customers and partners. Through their actions, the firms are continuously trying to convince their counterparts of their desirableness as an exchange partner. When faced with a changed network situation, as in the case of the interviewees, they needed to reconvince the network members. For example, in the case of Delta after the merger, the customer representatives that earlier on were highlighting what a technological innovator 
the company was ("why don't you advertise that you are the leading [special technology] supplier in the world") were now questioning the newly merged company's vision and willingness to continue with the same enthusiasm ("they were asking us what our own will was, what the company wanted to do for real"). At Alpha, they felt they were being considered outdated and therefore not a wanted partner for co-operation ("a stigma we have gained").

"It is currently visible that networking is not paying off. They think we are that different, they do not want to believe that we could change or be useful partners. I have been sensing that." (Alpha)

This trigger was not that visible, either in Beta or Gamma, since their network identity dissonance was only temporary (Beta) or was more internally based on the moving boundaries and attempts to redraw them (Gamma); their network image was not an actual trigger for a restart.

Perceived network identity dissonance. The identity crisis was initiated by a situation where the manager's understanding of who they are as a firm in relation to others did not correspond to the changing view he or she had on the network. Therefore, the identity dissonance is present in each restart strategizing, even if briefly. Dissonance was reflected not only in what business they saw they were in, but also in what they saw as defining their way of operating. If the manager was not able to find a balance between the internal and external identification features (Delta) and/or see them as changing whenever the underlying conditions changed (Alpha), the dissonance continued. Beta experienced their crisis when the strategy of working as a $100 \%$ subcontractor failed, but after that they have been more fluid strategy- and identity-wise and have been able to strike a balance between internal and external identification. Gamma was the only firm that refused to face an identity crisis - for them, their identity was stable even though the need for a restart was recognized. ("Even a bit embarrassing to say, but...if the firm had changed, of course I myself have not noticed that. The software 
firm, at its core, has not changed.")

\subsection{Resolving a start-up identity crisis: Restart strategizing}

The model of network strategizing depicted in Figure 2 suggests that the need for a restart as well as the modes of restart strategizing are the result of complex network dynamics and the attempts to balance the contradictions arising from the paradox of dependence/independence. When the established ways of dealing with these contradictions -previous modes of strategizing - are not working anymore, the firm faces a crisis. A firm's activities arise from their understanding of who they are (identification), and therefore their mode of strategizing is dependent on their identification and the boundaries drawn. Restart strategies arise from the attempt to learn to strategize anew and through that, identify themselves anew: to find a new balance by re-drawing and shifting boundaries mentally (e.g., envisioning a new position in a network, like Beta), socially (e.g., establishing new relationships with new kinds of business activities), and physically (e.g., sharing resources or merging).

The boundaries drawn at the start-up phase play an important role for future strategizing. Striking a balance between "who we are" and "who we are with" helps in defining "who we are becoming" - a feature needed in crisis resolution and in forming restart strategies. Re-start strategies are therefore about boundaries and the way they have been defining the balancing of contradictions for the firms. Beta and Delta were founded on subcontracting and positioned to be part of a strategic network with a certain hub firm. In that sense, the business network had clear, set boundaries. However, due to the identification of MB and MD through connecting their own competences, assumptions, and beliefs to the wider network, they saw the strategic network as well as the indeterminate nature of the network at the same time. For Beta, this situation was achieved after losing the first major client. Building on MBs professional experience and networks, Beta has been searching for partners to find better positions in wider 
networks. Being based on balancing inward-outward orientation and conscious search and creation of future opportunities, we call this restart strategy as Network leveraging. Delta, on the other hand, faced the crisis only after the merger. Their restart strategy Network identification was based on the quite opposite mindset of the parent company Epsilon, with a short-term orientation and organization-focused operations. Delta's aim was to get Epsilon to recognize the boundaries that had now emerged along with Delta's position in the strategic network.

For Beta and Delta, it was natural that the boundaries were set by themselves and that the business would be what they themselves made of it. This helped them in redrawing the boundaries when needed, both mentally and socially. The indetermination can already be seen in their vision statements explaining what their firms were about and what they wanted to achieve. For Beta and Delta, it was achieving something that others in that network would deem valuable and appreciate.

"What I was looking for with this merger was conquering the world. And I believe we would have an amazing opportunity to really take that step..." (Delta).

They form a contrast with Alpha and Gamma, for whom it was mostly about maintaining jobs and servicing those customers they were already familiar with through their employer. The mental and physical boundaries were set by the core idea of the business and related rules which were defined by the existing customer relationships:

"Because the customers for whom we were able to offer this service were all well-known. ... So I really didn't think about it any further." (Gamma)

As a result, the network that Alpha and Gamma were embedded in was closed with set social boundaries with the industry and a certain number of its actors. Since Alpha was dependent strategy-wise on their customers, also their future vision of themselves and drawing of boundaries accordingly depended on the partners they were able to find. Hence, Anchoring 
emerged as a restart strategy in a situation where the firm is drifting network-wise: while the view on the network changed from determined into indetermined, the focus was still in the organization and short-term operations. In other words, the operations lack focus until the firm is able to find a partner by which to define the boundaries. Re-inventing the business, on the other hand, is a strategy that cannot be managed with incremental changes: with operative focus and strong identification with a determined (but not strategic) network the boundaries remain fixed without a radical take-off. Due to the nature of the transformation, Gamma had recognized this need but chosen to postpone the inevitable actions.

To conclude, the choices made in the start-up phase create path dependency, and the difficulty of restarting depends on how well their strategizing deals with the innate contradictions of network strategy.

\section{DISCUSSION AND CONCLUSIONS}

The research question addressed by this study was How do firms strategize in a startup identity crisis within a network context? The broader aim of the study was to investigate the difficulties of small software firms, after their initial start-up phase, in changing their strategies along with changing network conditions while taking into account commitments made in the start-up phase. Based on the analysis, we identified elements that underlie the crisis and through which the crisis becomes visible to the managers. We are able to show restart strategizing to be about the interplay between moving boundaries and boundary-drawing, transforming identity and the shifting balances in the conflicting demands of strategizing, as depicted in Figure 2. Due to the different ways the firms have learned to deal with network strategy dynamics, they also follow that path in their search for restart strategies. Our findings provide several contributions to both theory and practice. 


\subsection{Theoretical contributions}

First, we introduce the notion of restart and restart strategies, referring to the need of the firms to reconsider the intangible and tangible engagements made in the start-up phase. Our study represents a closer examination of the actual strategic activities of start-ups in networks, aspects that have rarely been addressed in extant studies (La Rocca et al., 2013; Aaboen et al., 2016). In the start-up phase, strategists draw boundaries mentally, socially and physically when defining and organizing the business and establishing relationships with partners and customers, and this learned mode of strategizing becomes embedded in their practices. Firms become identified with the chosen network through the position they hold, and their network identity is then about who they are in light of their network connections. This idea of self is intertwined with their strategies: what their business is about, how they are operating and with whom. However, the boundaries are inherently unstable due to the dynamic nature of networks. As relationships are terminated and new ones created, and as actors leave and new ones enter, the boundaries drawn are continuously challenged.

All firms might face a need for restart in different times of their lives and therefore is not characteristic to only start-up strategizing. However, it is the first crisis that seems to define the way a firm learns to accept the inevitable change in their identities and strategies and learn to develop new ways to draw boundaries and identify themselves. The crisis is very real especially for software start-ups that have their strategies totally dependent on their clients and have experienced no need of questioning who there are: they exist, because their clients exist. They have had an identity in terms of a sense of self, but it is tied to operational issues and is indivisible from the client, as is their strategy from the client's strategy. Due to the strong dependence, their identity cannot develop without the identity crisis. Only after the internal and/or external triggers activate the existential questions of who the company is and who it wants to be, they will start to consciously strategize with the effort of finding their own path. 
Therefore, the implication for start-up research lies in examining start-ups' early strategizing activities and modes of strategizing. The contribution comes from the modeling of the dynamics of restart strategizing. The four firms under study responded to the crisis differently, and therefore followed a different mode of strategizing that was dependent on the situational conditions of each firm, but the dynamics behind their actions could be generalizable also to other contexts. Even though our four cases each represent different kinds of restart strategies, this does not mean that these would be the only possible modes of strategizing, nor does it imply that other firms could not follow a similar mode (like anchoring). More important is to understand that logic that underlies the strategizing activities of the firm. Our modeling of these dynamics depicts some of the key challenges of start-up strategizing to both the managers and the researchers.

Second, our findings contribute to network identity research by showing the continuity of forming of identities and strategies in a dynamic network context and the relatedness of the underlying dynamism with the conflicting interests of self and others. Consistent with the view of interaction in networks by Håkansson and Ford (2002), our results show that its paradoxical nature is due to the way managers create an understanding of their organization, both as an independent unit and dependent on the business relationships. The dynamics of network strategizing are about balancing three key contradictions relating to the paradox of dependenceindependence: being identified with both the organization and the network; innovating and stabilizing income streams; and creating a picture of the network that is defined and indeterminate at the same time.

Moreover, identity construction has been claimed to be a critical management issue since it indicates the attractiveness of the organization as an exchange partner (e.g., Purchase et al., 2016). However, the elaborated approach of organizational identities in networks (Huemer, 2013) adopted in this study highlights the importance of seeing network identity as an element 
of strategizing dynamics, related to the continuous building of inside-out and outside-in views of strategy. It is not the strength and stability of the identity that underlies successful strategizing. The adopted approach on identity construction as a continuous activity and identity being in continuous flux and transformation gives us a more practical insight into the way start-ups should be able to embrace this idea of transformation and adjust their strategizing accordingly.

Our findings have also implications for the ontological orientation adopted in both startup and identity research. Elaborating the ideas presented by Jing \& Van de Ven (2016) in their recent study, placing too much emphasis on the "central, enduring and distinctive" (Albert \& Whetten, 1985) features of networked organizations locks both researchers and managers into a "being" ontology, seeing the world consisting of things and leaving the underlying contradictions hidden. Instead, a "becoming" orientation would help us to embrace the dynamic nature of networks and see identities of organizations not as fixed but as something constantly in a constant transformation. "Being" refers to "a fixed, certain, and complete status or form of an existence before acquiring its relationships with other entities", while "becoming" is about "an interdependent and interactive process with other entities before and after any entity acquires its status or form" Li, 2016: 50). As Zhang et al. (2015: 560) noted, "paradoxically oriented leaders" are more able to deal with complex situations arising in dynamic environments. Since a contradiction can be interpreted as arising from cognitive limitations of managers - that is, how the issue is being framed by the managers - the solution can also come from dealing with these limitations (Jing \& Van de Ven, 2016; Jing \& Benner, 2016). "The art of balancing" (Jing \& Van de Ven, 2016) mindset would then be more important for managers than optimizing and aiming for stability.

\subsection{Managerial implications}


Our study holds several practical implications both for start-up managers as well as other actors that aim to help start-ups to develop. One of the key challenges in start-up creation and management relates to the "art of balancing" the contradictions. Despite the fact that a start-up tries to form internally a coherent identity, the views and actions of other actors in the network provide substantively the identity of the start-up. Traditionally, it is thought that to solve this contradiction, a start-up should have a distinct identity (for example, one built on an explicit business model) in order to discover a competitive advantage in the network. Based on the results of this study, however, it seems that for start-up managers, it is beneficial to favor a flexible and fluid approach to identity: that it is allowed to constantly evolve in relation to others. Strategizing to adapt to situations and changes in identity are natural parts of living in business networks. Changes are not a state of emergency, which should be eliminated in order to reimplement the original identity. Similarly, organizations that support start-ups should allow start-ups to have no clear identity (e.g. in terms of business plan, business model or management system). Instead, they should support the rapid learning of start-ups and (inter)active identity building in their network.

Another implication associated with setting up and running a start-up is that it is essential to develop effective strategizing skills. These come up as boundary-spanning and identification. These skills prepare the start-up to deal with unpredictable crises and survive when they happen. Managing the organization to cope with constant change is particularly important for a start-up because the company does not have the resources, legitimacy or bargaining power to survive without the support of others. On this basis, it is proposed that start-up managers should definitely do identity work outside-in in order to acquire coherence and common understanding. Nonetheless, they must also be strategically active inside-out and redefine their identity in relation to other actors. In this case, a change of identity is transformed from a threat into an opportunity through the skills to strategically shape themselves according 
to the changing network. Start-up support organizations often pay even too much attention to market, competitive, feasibility or financial analysis. Based on the results of this study, attention should also be paid to strategic skills of managers. Instead of passive analysis, the key to success is the active strategy making in its network. These skills should be appreciated and further developed by support organizations.

The third managerial implication is about the importance of questioning the strategic and contextual setting seen at the start-up. By challenging the existing network logics, start-ups can create space for themselves. This study suggests that an important form of this is strategic boundary work. Strategic boundary work links the existing and the new, allowing the start-up to manage its activities in a new way (cf. Santos \& Eisenhardt, 2009). Without interaction, crossing the borders for the purposes of new value creation cannot take place. This implication means that the identity of a start-up involves tolerance and exploitation of uncertainty, not risk minimization. A start-up should create itself by going beyond safe social, business, national and institutional boundaries. The support organizations, in turn, should be willing and able to facilitate activities that often produce a radical new business whose logics, form and identity are built upon action. This requires different mindset than supporting a more predictable managerial business.

In summary, based on the results of this study, it is possible to indicate that the dynamics should not be taken as interference that should be balanced in order to maintain an existing identity, but the dynamics are a permanent condition. An active interaction with the network and the continuous boundary-spanning, exploration of space, and dialogue on creating value prepare a start-up in advance for coping with the crises. Supporting organizations should therefore be able to support start-ups that through learning in networks create their identities, take an active strategy-making role in the network and aim to exploit network uncertainties for new value creation. 


\section{REFERENCES}

Aaboen, L., Dubois, A., \& Lind, F. (2011). Start-ups starting up - Firms looking for a network. The IMP Journal, 5(1), 42-58.

Aaboen, L., Laage-Hellman, J., Lind, F., Öberg, C., \& Shih, T. (2016). Exploring the roles of university spin-offs in business networks. Industrial Marketing Management, in press.

Aarikka-Stenroos, L., Sandberg, B., \& Lehtimäki, T. (2014). Networks for the commercialization of innovations: A review of how divergent network actors contribute. Industrial Marketing Management, 43(3), 365-381.

Albert, S., \& Whetten, D. A. (1985). Organizational identity. In L. L. Cummings, \& B. M. Staw (Eds.), Research in organizational behaviour, 7. (pp. 263-295). Greenwich, CT: JAI.

Albert, S., Ashforth, B. E., \& Dutton, J. E. (2000). Organizational identity and identification: Charting new waters and building new bridges. Academy of Management Review, 25(1), $13-17$.

Aldrich, H. E., \& Zimmer, C. (1986). Entrepreneurship through social networks. In D. Sexton, \& R. Smilor (Eds.), The art and science of entrepreneurship. Cambridge, MA: Ballinger.

Alvesson, M. (2001). Knowledge work: Ambiguity, image and identity. Human Relations, 54(7), 863-886.

Anderson, J. C., Håkansson, H., \& Johanson, J. (1994). Dyadic business relationships within a business network context. Journal of Marketing, 58(4), 1-15.

Araujo, L., \& Easton, G. (1996). Networks in socioeconomic systems: A critical review. In D. Iacobucci (Ed.), Networks in marketing (pp. 63-107). Thousand Oaks, CA: SAGE Publications, Inc.

Ashforth, B. E., \& Mael, F. A. (1996). Organizational identity and strategy as a context for the individual. In J. A. C. Baum, \& J. E. Dutton (Eds.), Advances in strategic management, 
vol. 13 (pp. 19-64). Greenwich, CT: JAI Press.

Baraldi, E., \& Strömsten, T. (2009). Controlling and combining resources in networks - from Uppsala to Stanford, and back again: The case of a biotech innovation. Industrial Marketing Management, 38(5), 541-552.

Baraldi, E., Gregori, G. L., \& Perna, A. (2011). Network evolution and the embedding of complex technical solutions: The case of the Leaf House network. Industrial Marketing Management, 40(6), 838-852.

Baraldi, E., \& Havenvid, M. I. (2016). Identifying new dimensions of business incubation: A multi-level analysis of Karolinska Institute's incubation system. Technovation, 50, 5368.

Baraldi, E., Ingemansson, M., \& Launberg, A. (2014). Controlling the commercialisation of science across inter-organisational borders: Four cases from two major Swedish universities. Industrial Marketing Management, 43(3), 382-391.

Birks, M., \& Mills, J. (2011). Grounded Theory: A Practical Guide. London: Sage Publications.

Birley, S. (1985). The role of networks in the entrepreneurial process. Journal of Business Venturing, 1(1), 107-117.

Bonner, J. M., Kim, D., \& Cavusgil, T. (2005). Self-perceived strategic network identity and its effects on market performance in alliance relationships. Journal of Business Research, 58(10): 1371-1380.

Bosch, J., Olsson, H. H., Björk, J., \& Ljungblad, J. (2013). The early stage software startup development model: A framework for operationalizing lean principles in software startups. In B. Fitzgerald, K. Conboy, K. Power, R. Valerdi, L. Morgan, \& K.-J. Stol (Eds.), Lean enterprise software and systems (pp. 1-15). Heidelberg: Springer.

Burgel, O., \& Murray, G. C. (2000). The international market entry choices of start-up 
companies in high-technology industries. Journal of International Marketing, 8(2), 3362.

Cerulo, K. A. (1997). Identity construction: New issues, new directions. Annual Review of Sociology, 23, 385-409.

Dutton, J. E., \& Dukerich, J. M. (1991). Keeping an eye on the mirror: Image and identity in organizational adaptation. Academy of Management Journal, 34(3): 517-554.

Ellis, N., Rod, M., Beal, T., \& Lindsay, V. (2012). Constructing identities in Indian networks: Discourses of marketing management in inter-organizational relationships. Industrial Marketing Management, 41(3), 402-412.

Epstein, C.F. (1992). Tinker-bells and pinups: the construction and reconstruction of gender boundaries at work. In: Lamont, M. \& Fournier, M. Cultivating Differences: Symbolic Boundaries and the Making of Inequality. Chicago: Univ. Chicago Press, pp. 232-56.

Farjoun, M. (2017). Contradictions, dialectics and paradoxes. In: Langley, A. \& Tsoukas, H. (Eds.): The SAGE Handbook of Process Organization Studies. Thousand Oaks: Sage.

Fiol, C. M. (2002). Capitalizing on paradox: The role of language in transforming organizational identities. Organization Science, 13(6), 653-666.

Gadde, L.- E., \& Håkansson, H. (2001). Supply network strategies. Chichester: JohnWiley \& Sons.

Gadde, L. -E., Huemer, L., \& Håkansson, H. (2003). Strategizing in industrial networks. Industrial Marketing Management, 32(5), 357-364.

Gioia, D. A., \& Chittipeddi, K. (1991). Sensemaking and sensegiving in strategic change initiation. Strategic Management Journal, 12(6), 433-448.

Gioia, D. A., Corley, K. G., \& Hamilton, A. L. (2013). Seeking qualitative rigor in inductive research notes on the Gioia methodology. Organizational Research Methods, 16(1), 1531. 
Gioia, D. A., Schultz, M., \& Corley, K. G. (2000). Organizational identity, image, and adaptive instability. Academy of Management Review, 25(1), 63-81.

Glaser, B. G., \& Strauss, A. L. (1967). The discovery of grounded theory: Strategies for qualitative research. London: Wiedenfeld and Nicholson.

Greenwood, R., \& Suddaby, R. (2006). Institutional entrepreneurship in mature fields: The big five accounting firms. Academy of Management Journal, 49(1), 27-48.

Håkansson, H., \& Ford, D. (2002). How should companies interact in business networks. Journal of Business Research, 55(2), 133-139.

Håkansson, H., \& Snehota, I., \& (Eds.). (1995). Developing relationships in business networks. London: Routledge.

Hatch, M.J. \& Schultz, M. (2002). The dynamics of organizational identity. Human Relations 55: 989.

Hoang, H., \& Antoncic, B. (2003). Network-based research in entrepreneurship: A critical review. Journal of Business Venturing, 18(2), 165-187.

Heracleous, L. 2004. Boundaries in the study of organization. Human Relations 57(1), 95-103.

Hernes, T. (2004) Studying composite boundaries: A framework of analysis. Human Relations, 57(1), 9-29.

Hernes, T., \& Paulsen, N. (2003). Introduction: Boundaries and organization. In N. Paulsen, \& T. Hernes (Eds.), Managing boundaries in organizations: Multiple perspectives (pp. 113). Houndmills: Palgrave McMillan.

Hoch, D.J., Roeding, C.R., Purkert, G. \& Lindner, S.K. (1999). Secrets of Software Success: Management Insights from 100 software firms around the world. Boston, Harvard Business School Press.

Huemer, L. (2004). Balancing between stability and variety: Identity and trust trade-offs in networks. Industrial Marketing Management, 33(3), 251-259. 
Huemer, L. (2013). When in Rome, be(come) a Roman? An actor focus on identities in networks. Industrial Marketing Management, 42(7), 1112-1120.

Huemer, L., Becerra, M., \& Lunnan, R. (2004). Organizational identity and network identification: Relating within and beyond imaginary boundaries. Scandinavian Journal of Management, 20(1), 53-73.

Jing, R., \& Benner, M. (2016). Institutional regimes and path dependence: Case studies of the conversion of military firms in China. Journal of Management Studies, Vol. 53(4), 552579.

Jing, R., \& Van de Ven, A. H. (2016). Being versus becoming ontology of paradox management. Cross Cultural \& Strategic Management, 23(4), 1-9.

Johanson J. \& Mattsson L-G. (1988). Internationalisation in industrial systems - A network approach. In Ford (1997) (2nd ed.) Understanding Business Markets: Interaction, Relationships and Networks, 194-213. London: Dryden Press.

Johanson, J., \& Mattsson, L. -G. (1992). Network positions and strategic actions: An analytical framework. In B. Axelsson, \& G. Easton (Eds.), Industrial networks: A new view of reality (pp. 205-217). London: Routledge.

Keeble, D., \& Wilkinson, F. (1999). Collective learning and knowledge development in the evolution of regional clusters of high technology SMEs in Europe. Regional Studies, 33(4), 295-303.

Lamont, M., \& Molnár, V. (2002). The study of boundaries in social sciences. Annual Review of Sociology 28, 167-195.

La Rocca, A., Ford, D., \& Snehota, I. (2013). Initial relationship development in new business ventures. Industrial Marketing Management, 42(7), 1025-1032.

La Rocca, A., \& Snehota, I. (2014). Relating in business networks: Innovation in practice. Industrial Marketing Management, 43(3), 441-447. 
Lefebvre, H. (1991). The production of space. Oxford: Blackwell.

Li, P. P. (2016). Global implications of the indigenous epistemological system from the east: How to apply Yin-Yang balancing to paradox management. Cross Cultural \& Strategic Management, 23(1), 42-77.

Lincoln, Y. S., \& Guba, E. G. (1985). Naturalistic inquiry. Beverly Hills, CA: Sage.

Lindgren, M., \& Wåhlin, N. (2001). Identity construction among boundary-crossing individuals. Scandinavian Journal of Management, 17(3), 357-377.

Locke, K. (2001). Grounded theory in management research. London: Sage.

Mael, F. A., \& Ashforth, B. E. (1992). Alumni and their alma mater: A partial test of the reformulated model of organizational identification. Journal of Occupational Behavior, 13(2), 103-123.

Mattsson, L. -G. (1988). Management of strategic change in a 'markets-as-networks' perspective. In A. Pettigrew (Ed.), The management of strategic change. Chichester: John Wiley.

McGrath, H., \& O'Toole, T. (2013). Enablers and inhibitors of the development of network capability in entrepreneurial firms: A study of the Irish micro-brewing network. Industrial Marketing Management, 42(7), 1141-1153.

Mintzberg, H., Ahlstrand, B., \& Lampel, J. (1998). Strategy Safari. London: FT/Prentice Hall. Naudé, P., Zaefarian, G., Tavani, Z. N., Neghabi, S., \& Zaefarian, R. (2014). The influence of network effects on SME performance. Industrial Marketing Management, 43(4), 630641.

Öberg, C. (2010). Customer roles in innovations. International Journal of Innovation Management, 14(06), 989-1011.

Öberg, C., Grundström, C., \& Jönsson, P. (2011). Acquisitions and network identity change. European Journal of Marketing, 45(9/10), 1470-1500. 
Oliver, C. (1992). The antecedents of deinstitutionalization. Organization Studies, 13(4), 563588.

O'Malley, L., O'Dwyer, M., McNally, R. C., \& Murphy, S. (2014). Identity, collaboration and radical innovation: The role of dual organisation identification. Industrial Marketing Management, 43(8), 1335-1342.

Palo, T., \& Tähtinen, J. (2013). Networked business model development for emerging technology-based services. Industrial Marketing Management, 42(5), 773-782.

Paternoster, N., Giardino, C., Unterkalmsteiner, M., Gorschek, T., \& Abrahamsson, P. (2014). Software development in startup companies: A systematic mapping study. Information and Software Technology, 56(10), 1200-1218.

Prashantham, S., \& Birkinshaw, J. (2008). Dancing with gorillas: How small companies can partner effectively with MNCs. California Management Review, 51(1), 6-23.

Pratt, M. G., \& Foreman, P. O. (2000). Classifying managerial responses to multiple organizational identities. Academy of Management Review, 25(1), 18-42.

Purchase, S., Da Silva Rosa, R., Schepis, D. (2016). Identity construction through role and network position. Industrial Marketing Management, 54, 154-163.

Ravasi, D., \& Schultz, M. (2006). Responding to organizational identity threats: Exploring the role of organizational culture. Academy of Management Journal, 49(3), 433-458.

Reger, R. K., Mullane, J. V., Gustafson, L. T., \& DeMarie, S. M. (1994). Creating earthquakes to change organizational mindsets. Academy of Management Journal, 8(4): 31-43.

Rindova, V., \& Fombrun, C. (1998). The identity of organizations. In D. A. Whetten \& P. C. Godfrey (Eds.), Identity in organizations: Building theory through conversations (pp. 33-83). Thousand Oaks, CA: Sage.

Ruokolainen, J., \& Igel, B. (2004). The factors of making the first successful customer reference to leverage the business of start-up software company - multiple case study in 
Thai software industry. Technovation, 24(9), 673-681.

Santos, F. M. \& Eisenhardt, K. M. (2009). Constructing markets and shaping boundaries: Entrepreneurial power in nascent fields. Academy of Management Journal, 52(4), 643671.

Schepis, D., Purchase, S., \& Ellis, N. (2014). Network position and identity: A language-based perspective on strategizing. Industrial Marketing Management, 43(4), 582-591.

Scott, W. R. (1995). Institutions and organizations. Thousand Oaks, CA: Sage.

Scott, S. G., \& Lane, V. R. (2000). A stakeholder approach to organizational identity. Academy of Management Review, 25(1), 43-62.

Selznick, P. (1957). Leadership in administration: A sociological interpretation. Berkeley. Cal. Smith, W., \& Lewis, M.W. (2011). Toward a theory of paradox: A dynamic equilibrium model of organizing. Academy of Management Review 36(2), 381-403.

Somers, M. R. (1994). The narrative constitution of identity: A relational and network approach. Theory and Society, 23(5), 605-649.

Strauss, A., \& Corbin, J. (1998). Basics of qualitative research: Techniques and procedures for developing grounded theory. Thousand Oaks, CA: Sage

Strömsten, T., \& Waluszewski, A. (2012). Governance and resource interaction in networks. The role of venture capital in a biotech start-up. Journal of Business Research, 65(2), $232-244$

Urquhart, C. and Fernandez, W. (2006). Grounded theory method: The researcher as blank slate and other myths. ICIS 2006 Proceedings.

Uzzi, B. (1997). Social structure and competition in interfirm networks: The paradox of embeddedness. Administrative Science Quarterly, 42(1), 35-67.

Väyrynen, K. \& Kinnula, M. (2012). Differences between success factors of IS quasioutsourcing and conventional outsourcing collaboration: a case study of two Finnish 
companies. Electronic Markets 22(1), 49-61.

Zhang, Y., Waldman, D. A., Han, Y. L., \& Li, X. B. (2015). Paradoxical leader behaviors in people management: Antecedents and consequences. Academy of Management Journal, $58(2), 538-566$. 
FIGURE 1

Strategizing through boundary-drawing and identification.

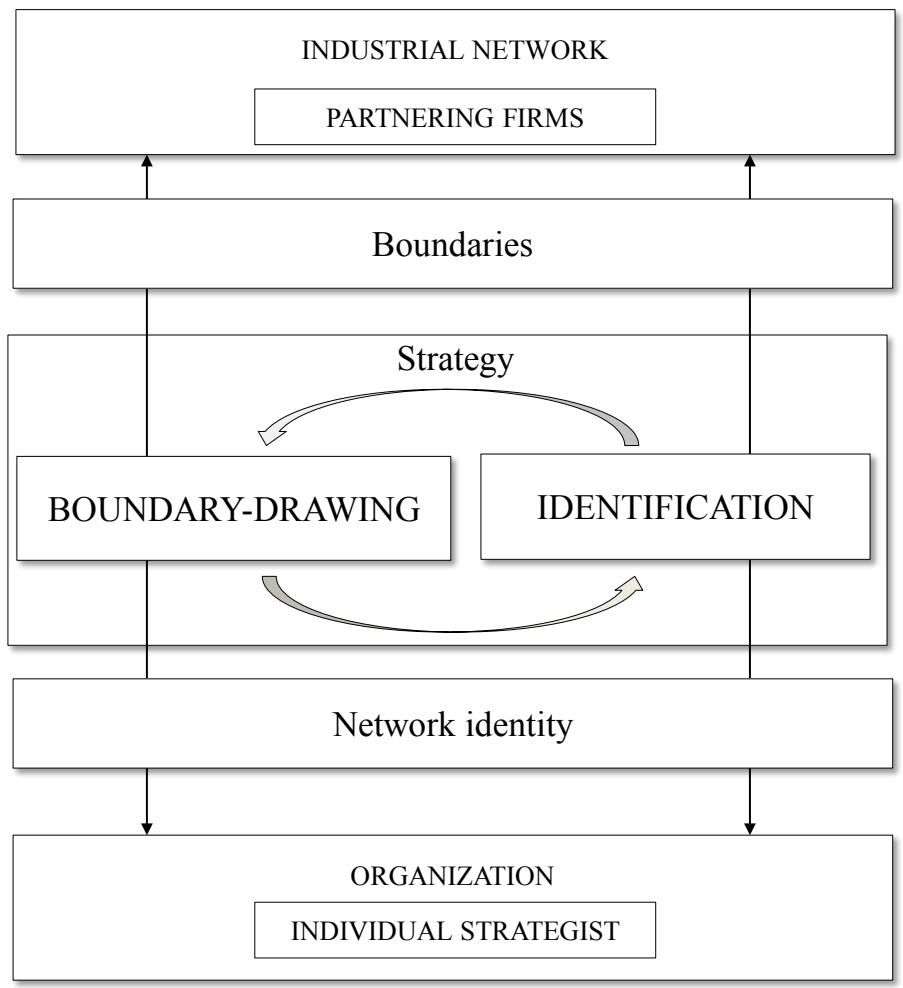


FIGURE 2

Dynamics of restart strategizing.

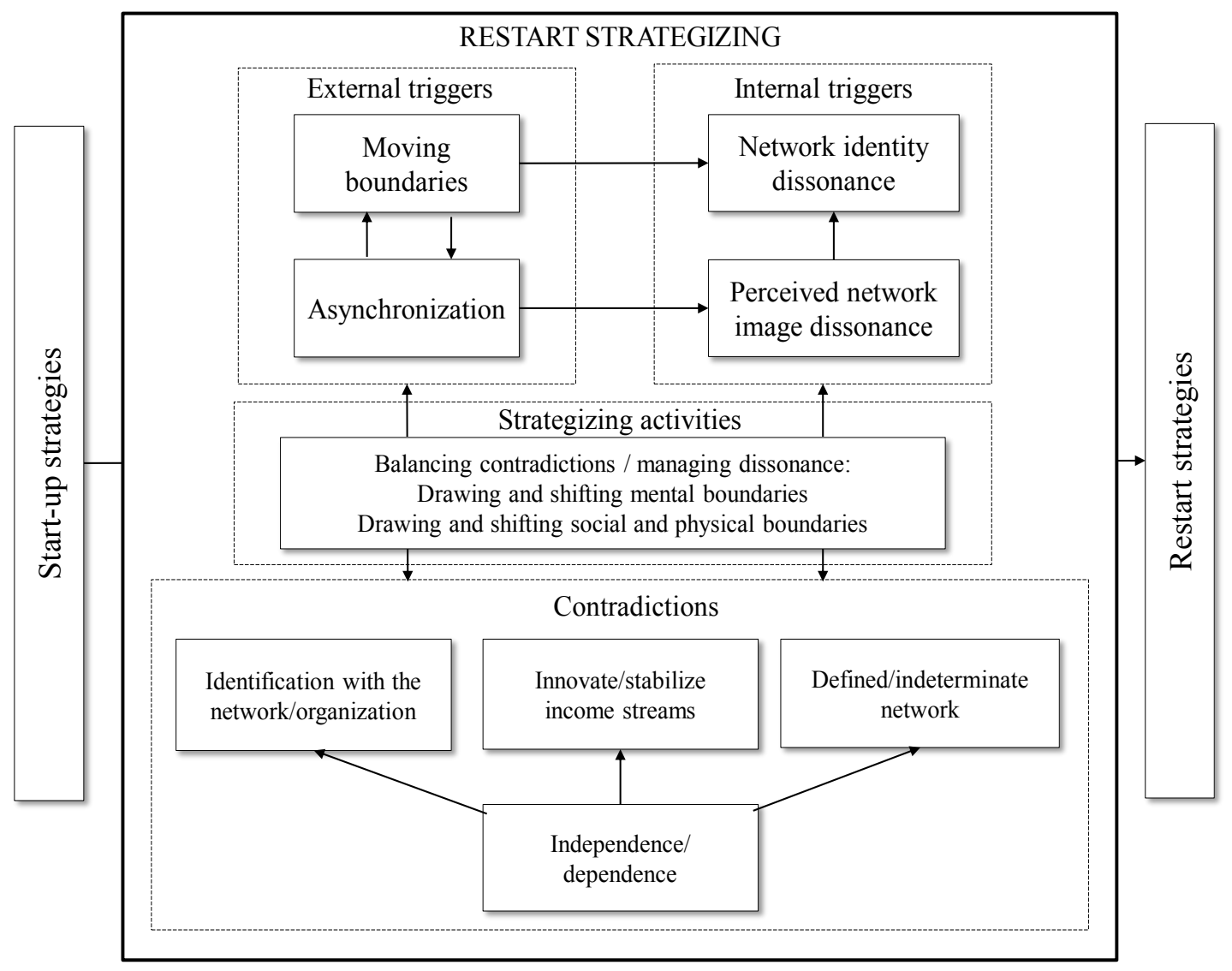


TABLE 1

Case firms

\begin{tabular}{|c|c|c|c|c|}
\hline & ALPHA & BETA & GAMMA & $\overline{\text { DELTA }}$ \\
\hline $\begin{array}{l}\text { Products and } \\
\text { services }\end{array}$ & $\begin{array}{l}\text { Enterprise systems } \\
\text { Projects, } \\
\text { technology, } \\
\text { expertise sales }\end{array}$ & $\begin{array}{l}\text { Software } \\
\text { subcontracting } \\
\text { Software production } \\
\text { projects } \\
\text { Consultation, } \\
\text { processes, definition } \\
\text { work } \\
\text { Platform and } \\
\text { products }\end{array}$ & GIS map systems & $\begin{array}{l}\text { Software } \\
\text { subcontracting/ } \\
\text { consultation, } \\
\text { development, test } \\
\text { laboratory and } \\
\text { production test } \\
\text { systems }\end{array}$ \\
\hline $\begin{array}{l}\text { Business area } \\
\text { of expertise }\end{array}$ & $\begin{array}{l}\text { Food industry } \\
\text { Health care } \\
\text { Soil processing } \\
\text { Operations control } \\
\text { Tele operators } \\
\text { Patient } \\
\text { administration } \\
\text { Trade } \\
\text { Logistics }\end{array}$ & $\begin{array}{l}\text { Software business } \\
\text { operation } \\
\text { Logistics, } \\
\text { transportation } \\
\text { IT and production } \\
\text { industry } \\
\text { Data center services }\end{array}$ & $\begin{array}{l}\text { Forest industry and } \\
\text { wood production }\end{array}$ & $\begin{array}{l}\text { Telecommunication / } \\
\text { Electronic devices } \\
\text { and systems, } \\
\text { software, industrial } \\
\text { internet }\end{array}$ \\
\hline Type of crisis & $\begin{array}{l}\text { Declining industry, } \\
\text { no new position in } \\
\text { sight }\end{array}$ & $\begin{array}{l}\text { Loss of a major } \\
\text { client }\end{array}$ & $\begin{array}{l}\text { Declining industry, } \\
\text { no new position in } \\
\text { sight }\end{array}$ & $\begin{array}{l}\text { Merging Delta with a } \\
\text { larger firm }\end{array}$ \\
\hline
\end{tabular}


TABLE 2

Interview data of the study.

\begin{tabular}{lll}
\hline Company and the interviewee & Theme & Date \\
\hline Alpha, MA & Business start-up 1/2 & 2.5 .2006 \\
Alpha, MA & Business start-up 2/2 & 3.5 .2006 \\
Alpha, MA & Managing the business & 30.5 .2006 \\
Alpha, MA & Renewal of business & 23.5 .2006 \\
Alpha, MA & Strategy formation & 16.6 .2008 \\
Alpha, new CEO & Strategy formation & 17.6 .2008 \\
Beta, MB & Business start-up & 18.4 .2006 \\
Beta, MB & Managing the business & 27.4 .2006 \\
Beta, MB & Biography & 16.5 .2006 \\
Beta, MB & Renewal of business & 2.5 .2006 \\
Beta, MB & Strategy formation & 28.5 .2008 \\
Beta, COO & Strategy and sales & 22.8 .2007 \\
Beta, COO & Strategy formation & 5.6 .2008 \\
Beta, new CEO & Strategizing practices & 20.12 .2010 \\
Beta, new CEO (ACP interview) & Future directions & 21.1 .2013 \\
Beta, new CEO (ACP interview) & Future directions & 22.1 .2014 \\
Beta, new CEO (ACP interview) & Future directions & 21.11 .2014 \\
Gamma, MG & Business start-up & 12.4 .2006 \\
Gamma, MG & Managing the business & 18.4 .2006 \\
Gamma, MG & Biography & 26.4 .2006 \\
Gamma, MG & Strategy formation & 18.6 .2008 \\
Gamma, new CEO & Future directions & 3.10 .2012 \\
Delta, MD & Business start-up & 5.7 .2006 \\
Delta, MD & Managing the business & 29.8 .2006 \\
Delta, MD & Renewal of business & 20.9 .2006 \\
\hline & & \\
& &
\end{tabular}


TABLE 3

Data structure.

\begin{tabular}{ll}
\hline 1st order concepts & 2nd order themes \\
\hline Existing client/-ele break-up. & Moving boundaries \\
Industry-wide transformation. & \\
Re-organizing through mergers. & \\
We are pondering whether we are doing the right thing, or should \\
we focus on some other area. \\
The aim for the merger was "conquering the world". \\
$\begin{array}{l}\text { Getting involved with new things too late; when the move is } \\
\text { finally made, there are others already. }\end{array}$
\end{tabular}

We were told that, if we don't move now, we will be too late.

We don't actively create our future, we will take what we get; even the customer representatives ask what kind of role we would like to take in this business for real.

We have been executing the past; should think about the customer needs.

Customer representatives asking what is our own will, what the company actually wants to do.

\section{Perceived network image dissonance}

Others see us as old-fashioned. Networking is not paying off; they think we are that different. But we are the ones creating our own paths; that's the stigma we have gained.

Seeing innovation and giving to (not only receiving from) the network is crucial for maintaining relationships; current situation is not corresponding to this vision.

Trying out different things, but not been able to figure out what would be the future business.

Customers guide our actions totally.

Merger changed the organization making it more inflexible; distance between people growing; not caring so much for the employees or the customers.

The subcontractors of subcontractors located in the outskirts of the network carry all the risks.

Independent module development options: the client is not that independent from the subcontractor, the subcontractor must be kept alive so that the module will live and have continuity.

We are doing work based on our own vision, and not on the terms of the customer; we have been active.

Customers guide the product development...the firm runs like a ram in a tether.

If the demand by customers were there, development would be natural. But now we just aim to serve them.

\section{Perceived network identity dissonance}

\section{Independence and dependence}

Aggregate

dimensions

Triggers of restart

\author{
Balancing \\ contradictions
}


Talking about 'we' inside the organization when referring to the network; not committed to the firm but to the network.

If an OEM has a problem, it is everybody's problem in that strategic network.

Organization is defined by the network: instead of being a subcontractor's subcontractor, trying to step up in the network and get closer to the customer.

Now the aim is to take all the money out and not use it in research and development; a pioneer position is lost when you only do what others tell you to do.

The main objective has been to stabilize the operation and make the operation profitable.

People learn through customer projects and they bring food to the table in small firms, but they reserve the resources and make it difficult to find resources for internal product development.

Unlike product development, customer projects require quite heterogeneous skills.

When customer projects take $100 \%$ of the resources, there is no internal development.

Several larger customers-partners helping to balance the business fluctuations; defined through the partners but indeterminate in terms of business opportunities matching the competence portfolio.

Closed network, only few customers remaining.

Not yet decided in which business the company is in; producing different solutions to different individual customers.

Trying to move from the outer layers of the network closer to the core.

From local to global networks.

Maintaining the vision of the leading sub-technology provider as a subcontractor of the leading technology provider.

Mission of leveraging the client's business.

Searching for a partner through whom to create a stronger link to a network.

Need for re-inventing the business has been recognized, but the owner-manager is just aiming to maintain status quo until the next owner takes over.
Identification with

the network and

identification with

the organization

Innovate and

stabilize income

streams

Defined and

indetermined

network

Network leveraging Restart strategizing

Network

identification

Anchoring

Postponed actions -

re-inventing the

business 